\title{
Opinion on Release Issue - Intellectual Property Rights: Open Access Volume 4 Issue 1
}

\section{Uqbah lqbal*}

School of History, Politics and Strategy, Faculty of Social Sciences and Humanities, UKM 43650, BangiSelangor, Malaysia

Intellectual Property Rights: Open Access (ISSN: 2375-4516) provides Tri-annual publication of articles in all areas related to the fields of Copyrights, Intellectual Property Rights, Ethics, Legal Rights, Litigation, Merchandising, Patent Law, Trade Mark and Trade Secrets. As a member of Publishers International Linking Association, the journal follows the Creative Commons Attribution License and Scholars Open Access publishing policies. The journal is the Council Contributor Member of Council of Science Editors (CSE) and following the CSE slogan Education, Ethics, and Evidence for Editors. Intellectual Property Rights: Open Access is organized by OMICS International, a self-supporting organization and does not receive funding from any institution or government. Hence, the operation of the journal is solely financed by the handling fees received from authors and some academic or corporate sponsors. Its Editor-in-Chief is Professor Michael Blakeney from Faculty of Law, University of Western Australia.

Up to the time this article was written, the journal has been published for 10 issues. There is one issue in 2013, 5 issues in 2014, 3 issues in 2015 and 1 issue in 2016. Seven articles are included in its latest issue in June 2016; Zura Kakushadze in the article 'How to Pick a Career... or two' highlights three of his important principles in helping someone choose a career as well as other natures that must be possessed. Joelle Dountio Ofimboudem in the article 'Access to Medicines Implications of the South Africa Intellectual Property Rights from Publicly Financed Research and Development Act No. 51, 2008' talks about
The Intellectual Property Rights from Publicly Financed Research and Development Act No. 51, 2008 (the IPR Act). The Act seeks to ensure that intellectual property emanating from research that is funded by the government is identified, protected, utilized, commercialized and translated into finished goods for social, economic and other benefits. Junghee Han and Wangwoo Lee in the article 'Patenting Activity - A Proxy of the Technology Gap? The Case of Korea and China. Intel Prop Rights 'focuses on the question of whether the utilization of intellectual property rights could be a proxy of the technology gap that exists between China and Korea. Uqbah Iqbal in the article 'Travel to the Land below the Wind' discusses his experiences during his stay in Sabah, one of the states in Malaysia. Kumaran T and Citarasu T in the article 'Isolation and Characterization of Vibrio Species from Shrimp and Artemia Culture and Evaluation of the Potential Virulence Factor' addresses the virulence and epidemiology of vibrio pathogen; pathogenesis of its disease. Mike Adcock and Deryck Beyleveld in the article 'Morality in Intellectual Property Law: A Concept-Theoretic Framework' presents a 'concept-theoretic' position on the relationship between law and morality in any legal system that includes respect for human rights as a fundamental principle of the legal validity of its rules. Uqbah Iqbal in the article 'The Role of Shinto Religion as Reference to Look East Policy' highlighted books about the Shinto religion that can be read by the people of Malaysia especially in the success of Look East Policy. Of the 7 articles, the article 'How to Pick a Career ... or two' gets most of readings, namely 125 people from June-2016 until July 22, 2016.
*Corresponding author: Iqbal U, School of History, Politics and Strategy, Faculty of Social Sciences and Humanities, UKM 43650, BangiSelangor, Malaysia, Tel: +60389215555; E-mail: uqbah@siswa.ukm.edu.my

Received July 23, 2016; Accepted July 28, 2016; Published August 06, 2016

Citation: Iqbal U (2016) Opinion on Release Issue - Intellectual Property Rights: Open Access Volume 4 Issue 1. Intel Prop Rights. 4: e108. doi: 10.4172/23754516.1000e108

Copyright: @ 2016 lqbal U. This is an open-access article distributed under the terms of the Creative Commons Attribution License, which permits unrestricted use, distribution, and reproduction in any medium, provided the original author and source are credited. 